\title{
Effect of Fertilizer Level and Planting Distance on Soil pH, Growth, Fruit Size, Disease Incidence, Yield, and Profit of Two Papaya Varieties ${ }^{1}$
}

\author{
A. Pérez and D. Vargas²
}

\begin{abstract}
Papaya production in Puerto Rico is low, probably because of diseases and poor management practices. In this study, high yielding varieties were used to compare planting distances and fertilizing practices.

Plants of varieties PR $6-65$ and PR $7-65$, planted at $1.8 \times 1.8 \mathrm{~m}$ were significantly larger than those at $1.2 \times 1.2 \mathrm{~m}$. The larger size of the plants was reflected in an increase in fruit yield and net profit.

PR 6-65 produced a significantly heavier crop and a higher net profit/ha than PR 7-65.

PR 6-65 was significantly more susceptible to the Isabela mosaic disease and more tolerant to bunchy top than PR 7-65. Soil pH was significantly lower at the $1.2 \times 1.2 \mathrm{~m}$ planting distance than at the $1.8 \times 1.8 \mathrm{~m}$, probably because more fertilizer was used in the closer planting.

There were no significant differences between the mean yields of papaya plants receiving monthly applications of .227 and $.454 \mathrm{~kg}$ of a 15-15-15 fertilizer, suggesting that the smaller amount of fertilizer is enough to produce a heavy crop and obtain a good net profit from papayas grown in Coto clay, an Oxisol.
\end{abstract}

\section{INTRODUCTION}

There is a big demand for papayas in Puerto Rico. They are used as fresh fruit, for industrial processing, and for the extraction of papain.

Yields of papaya in Puerto Rico are limited, mainly due to the bunchy top (mycoplasma), several virus diseases, insects, and nematodes, although there are varieties resistant or tolerant to these pathogens. Papaya plantations in Puerto Rico, furthermore, are generally not adequately managed.

During 1972, Puerto Rico imported from the Dominican Republic 851 tons of green papayas for industrial processing (1), at a farm value of about $\$ 102,000$. This situation suggests the possibility of increasing the commercial development of papayas in the Island.

This study was designed to determine the effect of two planting distances and two fertilizer levels on the fresh and dry weight of blades and petioles, stem diameter, stem height, soil pH, incidence of bunchy top and mosaic disease, fruit production, and net profit. The plan was to fertilize and manage the crop in such a way that the plants would develop fast enough to produce high yields before pathogens could seriously affect the plants and thus reduce yields.

${ }^{1}$ Manuscript submitted to Editorial Board February 2, 1976.

${ }^{2}$ Associate Horticulturist and Associate Economist, Agricultural Experiment Station, Mayagüez Campus, University of Puerto Rico, Río Piedras, P.R. 


\section{MATERIALS AND METHODS}

The experiment was conducted at Isabela Substation, in northwestern Puerto Rico at $130 \mathrm{~m}$ above sea level. Mean annual rainfall is $1,600 \mathrm{~mm}$. Annual mean maximum and minimum temperatures are $28^{\circ} \mathrm{C}$ and $19^{\circ} \mathrm{C}$, respectively. May is usually the rainiest month, whereas February is the driest.

The typical soil of the region is Coto clay, an Oxisol (Tropeptic Haplorthox) (6) with a permeable clayey surface to a depth of about 30 cm lying over a red-brown, permeable subsoil. According to Roberts (9) this soil contains about $3 \%$ organic matter, has a pH between 5.5 and 6.0 , and a base-exchange capacity between 7 and $10 \mathrm{meq} / 100 \mathrm{~g}$ of soil.

Planting was in May 1971 and harvesting was completed in April 1973.

Two papaya varieties (PR 6-65 and PR 7-65) were planted in $2^{3}$ factorial design at two spacings $(1.2 \times 1.2 \mathrm{~m}$ and $1.8 \times 1.8 \mathrm{~m})$, and fertilized at two levels (.227 and $.454 \mathrm{~kg} /$ plant/month) of a $15-15-15$ commercial fertilizer.

Before transplanting, the soil was sprayed with Aldrin ${ }^{3}$ at the rate of 1 $\mathrm{g}$ of the concentrated emulsion in $100 \mathrm{~g} /$ water/acre. Transplanting was done 60 days after seeding, when seedlings were about $0.6 \mathrm{~cm}$ in diameter and $30 \mathrm{~cm}$ tall. One week after transplanting, each hill received $113 \mathrm{~g}$ of the 15-15-15 commercial fertilizer. Thereafter, plants were fertilized monthly, increasing by $28 \mathrm{~g}$ of fertilizer per application until flower induction, at which time, each was given .227 or $.454 \mathrm{~kg}$ of fertilizer, depending on the treatment.

Furrow irrigation was supplied before fertilization and as needed.

The space between rows was cultivated two or three times with a sweep cultivator pulled by a 3,000 model rubber wheel tractor. Weeds left by the tractor were removed by hand. When the plants were too tall and cultivation could not be done with a tractor, Paraquat (Gramoxone) was used at the rate of 1 pint plus $236 \mathrm{~cm}^{3}$ of the X 77 spread sticker/100 gal of water for weed control.

The damage caused by the fruit fly, Toxotrypana curvicauda, which generally attacks small, recently set fruits, was repressed. with Thiodan (Endosulfan) at the rate of $0.68 \mathrm{~kg}$ plus $236 \mathrm{~cm}^{3}$ of the X. 77 spreadersticker/100 gal of water.

Growth was measured in December 1971, February 1972, and February 1973. Fresh and dry weights of 4 leaves/plot (blades and petioles were dried to a constant weight in a forced-air oven at $70^{\circ} \mathrm{C}$ ); stem diameter at $30.5 \mathrm{~cm}$ above ground level; and height to the terminal bud

\footnotetext{
${ }^{3}$ Trade names are used in this publication solely for the purpose of providing specific information. Mention of a trade name does not constitute a guarantee or warranty of equipment or materials by the Agricultural Experiment Station of the University of Puerto Rico or an endorsement over other equipment or materials not mentioned.
} 
were recorded at each date. The weights of female and hermaphroditic fruits were recorded in harvest of February 1972. The results were evaluated by Duncan's Multiple Range Test.

To determine whether fertilization had any effect on soil $\mathrm{pH}$, soil samples were collected at the termination of the experiment at the region of the feeder roots and analyzed.

The number of plants with bunchy top and mosaic diseases were recorded throughout the duration of the experiment as well as the overall number of diseased plants at the termination of the experiment.

Green fruits for processing were harvested in February, April, July, and October 1972 and in February and April 1973. All fruits weighing more than $0.5 \mathrm{~kg}$ were picked during each harvesting. The entire crop

TABLE 1.-Effect of planting distance on fresh and dry weights of blades and petioles of the PR 6-65 and PR 7-65 papaya varieties, Dec. 1971 and Sept. $1973^{1}$

\begin{tabular}{|c|c|c|c|c|c|}
\hline \multirow{3}{*}{ Planting distance } & \multirow{3}{*}{ Leaf } & \multicolumn{4}{|c|}{ Varieties } \\
\hline & & \multicolumn{2}{|c|}{ PR 6-65 } & \multicolumn{2}{|c|}{ PR 7-65 } \\
\hline & & Fresh & Dry & Fresh & Dry \\
\hline \multirow[t]{2}{*}{$M$} & & $G$ & $G$ & $G$ & $G$ \\
\hline & & 971 & & & \\
\hline \multirow[t]{2}{*}{$1.2 \times 1.2$} & Blade & $391 \mathrm{a}$ & $65 \mathrm{a}$ & $384 \mathrm{a}$ & $66 a$ \\
\hline & Petiole & $453 \mathrm{a}$ & $48 \mathrm{a}$ & $423 \mathrm{a}$ & $43 \mathrm{a}$ \\
\hline \multirow[t]{2}{*}{$1.8 \times 1.8$} & Blade & $427 \mathrm{~b}$ & $76 \mathrm{~b}$ & $444 \mathrm{~b}$ & $78 \mathrm{~b}$ \\
\hline & Petiole & $508 \mathrm{~b}$ & $55 \mathrm{~b}$ & $470 \mathrm{~b}$ & $55 \mathrm{~b}$ \\
\hline \multicolumn{6}{|c|}{ Sept. 1973} \\
\hline \multirow{2}{*}{$1.2 \times 1.2$} & Blade & $257 \mathrm{a}$ & $46 \mathrm{a}$ & $282 \mathrm{a}$ & $44 \mathrm{a}$ \\
\hline & Petiole & 305 a & $32 \mathrm{a}$ & $270 \mathrm{a}$ & $28 \mathrm{a}$ \\
\hline \multirow[t]{2}{*}{$1.8 \times 1.8$} & Blade & $303 \mathrm{~b}$ & $55 \mathrm{a}$ & $309 \mathrm{~b}$ & $58 \mathrm{a}$ \\
\hline & Petiole & $341 \mathrm{a}$ & $37 \mathrm{a}$ & $321 \mathrm{~b}$ & $34 \mathrm{a}$ \\
\hline
\end{tabular}

${ }^{1}$ Means in either rows or columns with different letters are significantly different at the 0.05 level.

was sold at $\$ 13.23 /$ cwt at the cannery, and the net profit/ha at each harvesting date was calculated.

\section{RESULTS AND DISCUSSION}

Table 1 shows that during December 1971 the fresh and dry weights of leaves from plants of the PR 6-65 and PR 7-65 varieties planted at $1.8 \times$ $1.8 \mathrm{~m}$ were significantly higher than from those planted at $1.2 \times 1.2 \mathrm{~m}$. When the same plants were sampled in September 1973 the difference was significant for fresh weight of blades. Dry weights of leaves of both varieties collected in September 1973 were significantly lower than those sampled in December 1971.

Table 2 shows the following results, disregarding varietal effect: a) Papaya plants spaced at $1.8 \times 1.8 \mathrm{~m}$ had higher blade and petiole fresh 
and dry weights than those planted at $1.2 \times 1.2 \mathrm{~m}$; b) at both planting distances, petioles had higher fresh weights and lower dry weights than blades, suggesting that the petiole, besides supporting the leaf blade, serves as a water storage tissue; c) increasing the fertilizer application from .227 to $.454 \mathrm{~kg} /$ plant decreased significantly the fresh weight of petioles from plants at $1.2 \times 1.2 \mathrm{~m}$ and increased significantly the fresh weight of blades and petioles of plants at $1.8 \times 1.8 \mathrm{~m}$; and d) the fertilizer level did not affect significantly the blade fresh weight in plants at $1.2 \times$

TABLE 2.-Effect of fertilizer levels and planting distances on fresh and dry weight of papaya blades and petioles during Dec. 1971

\begin{tabular}{|c|c|c|c|c|c|}
\hline \multirow[b]{2}{*}{ Fertilizer level } & \multicolumn{5}{|c|}{ Planting distance $\mathrm{cm}$} \\
\hline & \multicolumn{2}{|c|}{ Fresh } & \multicolumn{3}{|l|}{ 120 $x$ 120 } \\
\hline$G$ & $G$ & $G$ & $G$ & & $G$ \\
\hline \multicolumn{6}{|c|}{ Blades } \\
\hline 227 & $390 \mathrm{a}^{1}$ & $400 \mathrm{a}$ & $68 \mathrm{a}$ & & $70 \mathrm{a}$ \\
\hline 454 & $387 \mathrm{a}$ & $471 \mathrm{~b}$ & $62 \mathrm{a}$ & & $85 \mathrm{a}$ \\
\hline Mean & 389 a & $435 \mathrm{a}$ & $65 \mathrm{~b}$ & & $78 \mathrm{~b}$ \\
\hline \multicolumn{6}{|c|}{ Petioles } \\
\hline 227 & $323 \mathrm{~b}$ & 432 a & $45 \mathrm{a}$ & & $53 \mathrm{a}$ \\
\hline 454 & $403 \mathrm{a}$ & $547 \mathrm{~b}$ & $46 \mathrm{a}$ & & $57 \mathrm{a}$ \\
\hline Mean & $413 \mathrm{~b}$ & $489 \mathrm{~b}$ & $45 \mathrm{a}$ & & $55 \mathrm{a}$ \\
\hline
\end{tabular}

${ }^{1}$ Means in either rows or columns with different letters are significantly different at the 0.05 level.

TABLE 3.-Stem diameter in cm of papaya planted in February 1973 at $1.2 \times 1.2$ and 1.8 $\times 1.8 \mathrm{~m}$ and fertilized monthly with 227 and $454 \mathrm{~g}$ of fertilizer per plant

\begin{tabular}{cccc}
\hline \multirow{2}{*}{ Fertilizer level $(\mathrm{G})$} & \multicolumn{2}{c}{ Planting distance in $\mathrm{m}$} & \multirow{2}{*}{ Mean } \\
\cline { 2 - 3 } & $1.2 \times 1.2$ & $1.8 \times 1.8$ & \\
\hline 227 & $11.380 \mathrm{a}^{1}$ & $12.00 \mathrm{~b}$ & $11.68 \mathrm{a}$ \\
454 & $11.75 \mathrm{a}$ & $12.75 \mathrm{~b}$ & $12.25 \mathrm{~b}$ \\
Mean & $11.56 \mathrm{a}$ & $12.38 \mathrm{~b}$ & 11.97 \\
\hline
\end{tabular}

${ }^{1}$ Means in either rows or columns with different letters are significantly different at the 0.05 level.

$1.2 \mathrm{~m}$ and the dry weights of blades and petioles at either of the two planting distances.

Table 3 shows that papaya plants at $1.8 \times 1.8 \mathrm{~m}$ produce, irrespective of the fertilizer level, thicker stems than those planted at $1.2 \times 1.2 \mathrm{~m}$. It also shows that plants fertilized monthly with $.227 \mathrm{~kg}$ of fertilizer were thinner than those that received. $454 \mathrm{~kg}$.

Table 4 shows that PR 6-65 grows significantly taller at $1.8 \times 1.8 \mathrm{~m}$ than at $1.2 \times 1.2 \mathrm{~m}$. The opposite is true of PR 7-65. At age 21-months PR 6-65 was $0.52 \mathrm{~m}$ taller than PR 7-65; plants at $1.2 \times 1.2 \mathrm{~m}$ tended to be shorter than at $1.8 \times 1.8 \mathrm{~m}$. 
Results showing that leaf weights of mature plants were lower than those of young ones suggest that the latter may be more efficient in their photosynthetic function and, therefore, may induce higher yields. This could account for the higher yield usually obtained during the first 12 months of plant growth.

The petioles' serving as water-storage tissue, as reflected in the fresh weight, indicates that the fresh weight of petioles may be used as an index to determine the water needs of the papaya plant.

The lower leaf weight, stem diameter, and stem height of papaya plants at $1.2 \times 1.2 \mathrm{~m}$ than those at $1.8 \times 1.8 \mathrm{~m}$, could be attributed to lack of light for photosynthesis in the former.

The behavior of PR 7-65 at $1.2 \times 1.2 \mathrm{~m}$ suggests that this variety may be more affected by an etiolation response. The small size of PR 7-65 plants could be because they produce fruits younger than PR 6-65, suggesting that fruit production may cause a depressive effect on height.

TABLE 4.- Height in meters in Feb. 1973 of PR 6-65 and PR 7-65 papaya plants planted at $1.2 \times 1.2 \mathrm{~m}$ and $1.8 \times 1.8 \mathrm{~m}$

\begin{tabular}{|c|c|c|c|}
\hline \multirow{2}{*}{ Planting distance } & \multicolumn{2}{|c|}{ Height } & \multirow{2}{*}{ Mean } \\
\hline & PR 6-65 & PR 7-65 & \\
\hline$M$ & $M$ & $M$ & $M$ \\
\hline $1.2 \times 1.2$ & $4.19 \mathrm{a}^{1}$ & $3.94 \mathrm{~b}$ & $4.07 \mathrm{a}$ \\
\hline $1.8 \times 1.8$ & $4.54 \mathrm{~b}$ & $3.74 \mathrm{a}$ & $4.14 \mathrm{~b}$ \\
\hline Mean & $4.36 \mathrm{~b}$ & $3.84 \mathrm{a}$ & 4.10 \\
\hline
\end{tabular}

' Means in either rows or columns with different letters are significantly different at the 0.05 level.

Figure 1 shows that when female plants of PR 6-65 were fertilized monthly with $.454 \mathrm{~kg}$ they produced significantly smaller fruits than those with half as much fertilizer. Opposite results were obtained with the PR 7-65 variety.

In hermaphroditic plants of both PR 6-65 and PR 7-65, differently fertilized, there were no mean differences in fruit weight. Female and hermaphroditic fruits of PR 6-65 were significantly heavier than those of PR 7-65. Within each variety, irrespective of fertilizer treatment, hermaphroditic plants tended to produce heavier fruits than female plants.

Figure 2 shows that fruit weight from female plants in the two varieties did not differ significantly at the two planting distances. In hermaphroditic plants, fruits tended to be significantly heavier when plants were set at $1.8 \times 1.8 \mathrm{~m}$ than at $1.2 \times 1.2 \mathrm{~m}$.

Soil pH at termination of the experiment was 5.8 and 6.2 for the $1.2 \times$ $1.2 \mathrm{~m}$ and $1.8 \times 1.8 \mathrm{~m}$ planting distances, respectively. This difference was significant. The placement of fertilizer in concentrated bands, 


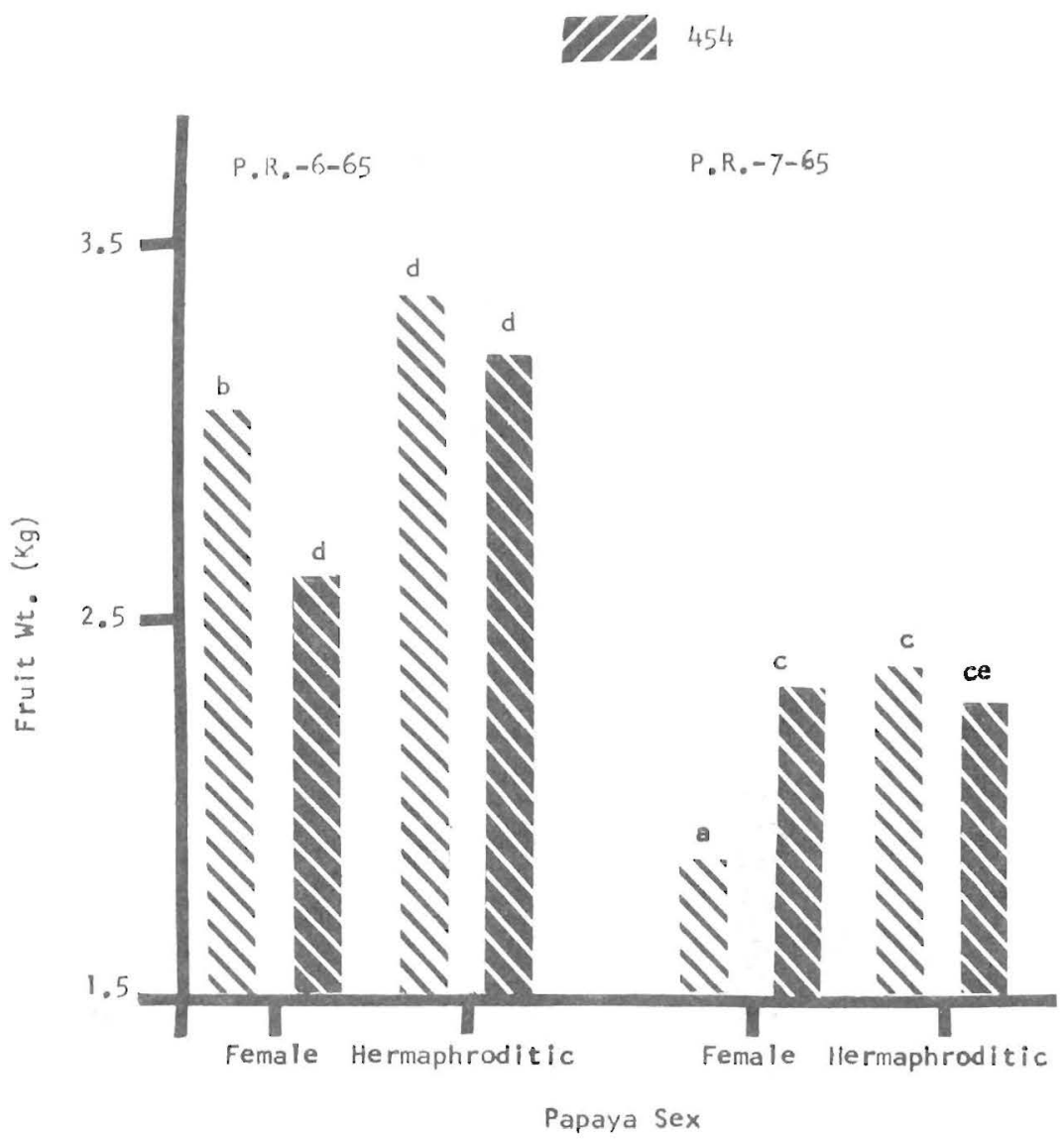

Fig. 1. - Effect of two fertilizer levels on the mean fruit weight (kg/fruit) of PR 6-65 and PR 7-65 papaya varieties.

required by the closer spacing, may have produced an acidifying effect. This interpretation is consistent with results obtained by Traub et al. (10).

Table 5 shows the percentage of papaya plants affected with bunchy top and mosaic diseases. Incidence of bunchy top was significantly lower and that of mosaic significantly higher in PR 6-65 than in PR 7-65.

As fruit production on plants receiving .227 and $.454 \mathrm{~kg}$ of fertilizer 
did not vary significantly, the results for the higher fertilizer level are not presented.

Table 6 indicates that only during the first fruit picking in February 1972, PR 7-65 produced significantly higher fruit weight than PR 6-65; in the other five pickings PR 6-65 outyielded PR 7-65. But the differences in fruit weight were statistically significant only in April and July 1972 pickings. The higher yield of PR 7-65 in the February 1972 picking was because this is an earlier variety than PR 6-65.

With the exception of the February 1972 harvest, the net profit during

Papaya Sex

$1 \%$ Female

2.2 Hermaphroditic

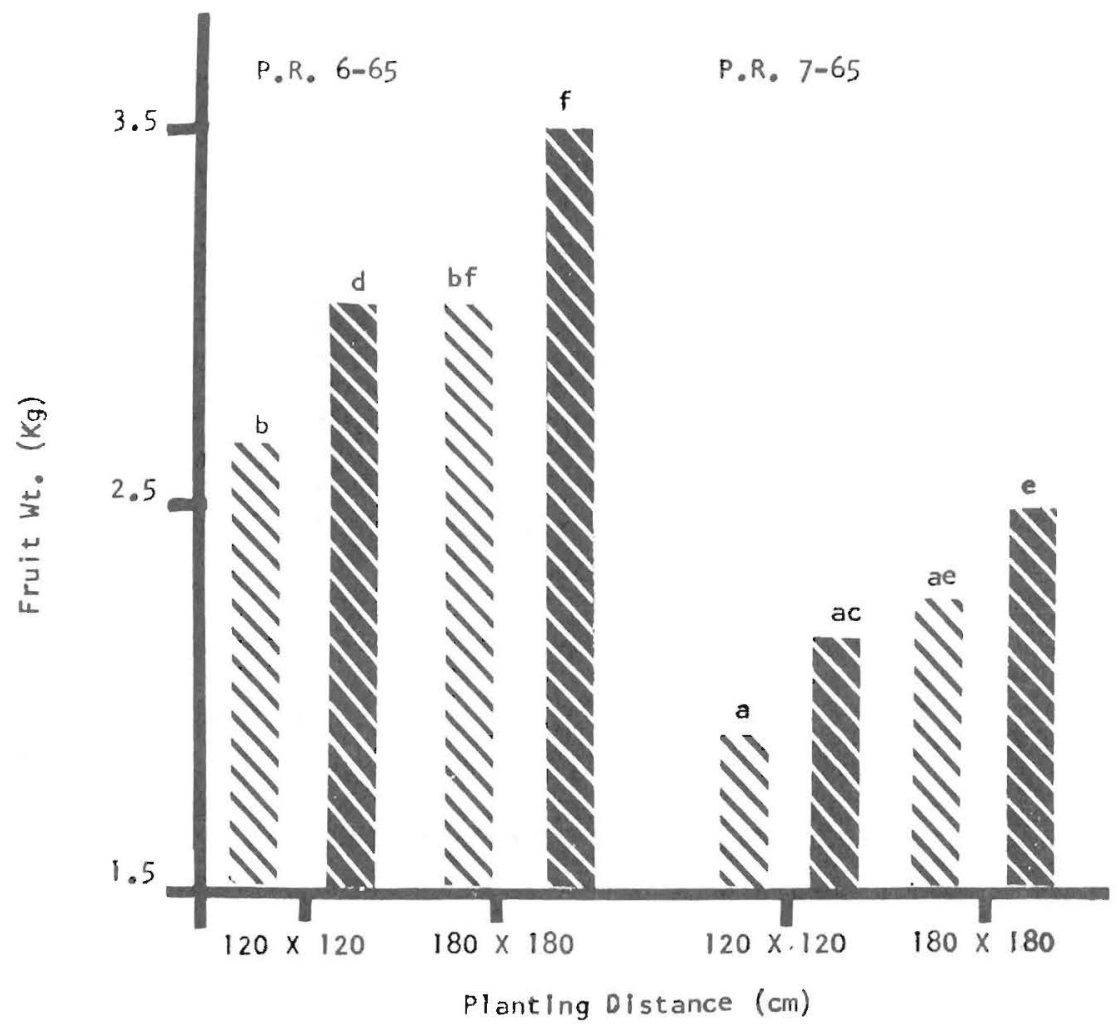

FIG. 2. - Effect of two planting distances on the mean fruit weight (kg/fruit) of PR 6 65 and PR 7-65 papaya varieties. 
TABLE 5.-Percent of PR 6-65 and PR 7-65 papaya plants affected with bunchy top and mosaic disease at end of experiment

\begin{tabular}{lcc}
\hline \multirow{2}{*}{ Disease } & \multicolumn{2}{c}{ Plants affected for variety } \\
\cline { 2 - 3 } & PR 6-65 & PR 7-65 \\
\hline Bunchy Top & $\%$ & $29 \mathrm{~b}$ \\
Mosaic & $11 \mathrm{a}^{1}$ & $37 \mathrm{a}$ \\
Total diseased & $54 \mathrm{~b}$ & 66 \\
\hline
\end{tabular}

${ }^{1}$ Means in rows with different letters are significantly different at the 0.05 level.

TABLE 6. - Fruit weight (cwt/ha) and net profit from fruits sold at $\$ 13.23$ per cwt from 6 pickings of $P R$ 6-65 and $P R$ 7-65 varieties planted at $1.2 \times 1.2 \mathrm{~m}$ and $1.8 \times 1.8 \mathrm{~m}$ and receiving $224 \mathrm{~g}$ of a 15-15-15 commercial fertilizer

\begin{tabular}{ccccccccc}
\hline $\begin{array}{c}\text { Planting } \\
\text { distance }\end{array}$ & & $\begin{array}{c}\text { Feb. } \\
1972\end{array}$ & $\begin{array}{c}\text { April } \\
1972\end{array}$ & $\begin{array}{c}\text { July } \\
1972\end{array}$ & $\begin{array}{c}\text { Oct. } \\
1972\end{array}$ & $\begin{array}{c}\text { Feb. } \\
1973\end{array}$ & $\begin{array}{c}\text { April } \\
1973\end{array}$ & Total \\
\hline$M$ & & & & & $P R 6-65$ & & & \\
$1.2 \times 1.2$ & $\mathrm{~F}^{1}$ & $420 \mathrm{a}^{2}$ & $256 \mathrm{a}$ & $349 \mathrm{~b}$ & $289 \mathrm{~b}$ & $191 \mathrm{a}$ & $54 \mathrm{a}$ & $1559 \mathrm{~b}$ \\
& $\mathrm{P}^{3}$ & 777 & 474 & 646 & 535 & 353 & 100 & 2885 \\
$1.8 \times 1.8$ & $\mathrm{~F}$ & $442 \mathrm{a}$ & $296 \mathrm{a}$ & $238 \mathrm{a}$ & $442 \mathrm{a}$ & $245 \mathrm{a}$ & $59 \mathrm{a}$ & $1822 \mathrm{a}$ \\
& $\mathrm{P}$ & $346 \mathrm{~b}$ & 2321 & 2650 & 3465 & 1921 & 463 & 14285 \\
& & & & & & & & \\
Total & $\mathrm{F}$ & $862 \mathrm{~b}$ & $552 \mathrm{a}$ & $687 \mathrm{a}$ & $731 \mathrm{a}$ & $436 \mathrm{a}$ & $113 \mathrm{a}$ & $3381 \mathrm{a}$ \\
& $\mathrm{P}$ & $42 \mathrm{z}$ & 2795 & 3296 & 4000 & $227 \mathrm{a}$ & 563 & 17170 \\
& & & & & & & & \\
& & & & & $P R 7-65$ & & & \\
$1.2 \times 1.2$ & $\mathrm{~F}$ & $583 \mathrm{a}$ & $231 \mathrm{a}$ & $136 \mathrm{~b}$ & $324 \mathrm{a}$ & $158 \mathrm{a}$ & $45 \mathrm{a}$ & $1477 \mathrm{~b}$ \\
& $\mathrm{P}$ & 770 & 305 & 180 & 428 & 209 & 69 & 1961 \\
$1.8 \times 1.8$ & $\mathrm{~F}$ & $515 \mathrm{a}$ & $198 \mathrm{a}$ & $255 \mathrm{a}$ & $309 \mathrm{a}$ & $225 \mathrm{a}$ & $49 \mathrm{a}$ & $1551 \mathrm{a}$ \\
& $\mathrm{P}$ & 3636 & 1398 & 1800 & 2182 & 1888 & 346 & 11250 \\
& & & & & & & & \\
Total & $\mathrm{F}$ & $1098 \mathrm{a}$ & $429 \mathrm{~b}$ & $391 \mathrm{~b}$ & $633 \mathrm{a}$ & $383 \mathrm{a}$ & $94 \mathrm{a}$ & $3028 \mathrm{~b}$ \\
& $\mathrm{P}$ & 4406 & 1703 & 1980 & 2610 & 2097 & 415 & 13211 \\
\hline
\end{tabular}

${ }^{1} \mathrm{~F}=$ Fruit weight (cwt/ha).

2 Mean separation within columns by Duncan's multiple range test at the 0.05 level.

${ }^{3} \mathrm{P}=$ Net profit $(\$ /$ ha $)$

the following five pickings was much higher in PR 6-65 than in PR 7-65. PR 6-65 outyielded PR 7-65 in total fruit production and total net profit. Net profit per hectare during the six pickings of both varieties was higher with plants set at $1.8 \times 1.8 \mathrm{~m}$ than with those at $1.2 \times 1.2 \mathrm{~m}$. Net profit between these two planting distances ranges from six- to twelvefold. The difference in net income between planting distances could be due to a higher expense for materials and seedlings when planted $1.2 \times$ $1.2 \mathrm{~m}$.

\section{RESUMEN}

La producción comercial de papayas es baja por la incidencia de enfermedades y, quizá, por ciertas prácticas tradicionales de cultivo. 
En este estudio se sembraron en un suelo Coto (Oxisol) dos variedades de alto potencial productivo (PR 6-65 y PR 7-65) a dos distancias de siembra con dos niveles de abono de análisis 15-15-15 aplicados mensualmente (.227 y .454 kg. por planta).

A una distancia de $1.8 \times 1.8 \mathrm{~m}$. (6 66 pies) las plantas fueron significativamente más altas que a $1.2 \times 1.2 \mathrm{~m}$. $(4 \times 4$ pies $)$. El tamaño de las plantas fue proporcional a la cosecha y a la ganancia neta. Esto quiere decir, que la papaya debe sembrarse a una distancia de $1.8 \times 1.8 \mathrm{~m}$. y no a $1.2 \times 1.2 \mathrm{~m}$.

Si el rendimiento se toma a base del peso total de las frutas, tanto el rendimiento como el beneficio de la PR 6-65 fueron significativamente mayores que los de la PR 7-65, lo que indica que la PR 6-65 debe preferirse para siembras comerciales.

PR 6-65 fue significativamente más susceptible al mosaico de Isabela y tolerante al "bunchy top" que la PR 7-65.

El pH del suelo fue significativamente más bajo a la distancia de $1.2 \times 1.2 \mathrm{~m}$. que a 1.8 $\times 1.8 \mathrm{~m}$., posiblemente debido a la mayor concentración del abono por área unitaria.

La diferencia en producción entre $.227 \mathrm{~kg}$. (1/2 lb) y. 454 (1 lb) de abono $15-15-15$ no fue estadísticamente significativa, lo cual indica que $.227 \mathrm{~kg}$ de este abono por mes es suficiente para lograr un buen beneficio, si se siembra en un suelo Oxisol (Coto arcilloso) como el usado en la prueba y bajo condiciones ecológicas similares a las de Isabela.

\section{LITERATURE CITED}

1. Anuario de Estadísticas Agrícolas de Puerto Rico 1971-72, Oficina de Estadísticas Agrícolas, Departamento de Agricultura del E. L. A., Santurce, Puerto Rico, 1972.

2. Awada, M., The selection of the nitrogen index in papaya tissue analysis, J. Amer. Soc. Hort. Sci. 94 (6): 687-90, 1969.

3. - and Long, C., The selection of the phosphorus index in papaya tissue analysis, J. Amer. Soc. Hort. Sci. 94 (5): 501-04, 1969.

4. - and The selection of the potassium index in papaya tissue analysis, $\mathrm{J}$. Amer. Soc. Hort. Sci. 96 (1): 74-7, 1971.

5. —- Suchisa, R., and Kanehiro, Y., Effects of lime and phosphorus on yield, growth, and petiole composition of papaya, J. Amer. Soc. Hort. Sci. 100 (3): 294-8, 1975.

6. Lugo-López, M. A., Bartelli, L. J., and Abruña, F., An overview of the soils of Puerto Rico: Classification and physical, chemical and mineralogical properties, Agr. Exp. Sta., Univ. P.R. Pub. 79, 1973.

7. Pérez, A., Effect of nitrogen and boron levels on growth, fruiting, mineral content, and fruit quality of Carica papaya L. Ph.D. Thesis, Rutgers-The State University, New Brunswick, N. J., 1970.

8. Reyes, J., and Rubén, D., Efecto de nitrógeno y boro en el crecimiento, producción y el contenido mineral de pecíolos y frutas de Carica papaya L., Tesis de M. C., Recinto de Mayagüez, Univ. P.R., Mayagüez, P.R., 1973.

9. Roberts, R. C., Soil survey of Puerto Rico, USDA, Series 1936 in cooperation with the Univ. P.R., Agr. Exp. Sta., 1942.

10. Traub, H. P., Robinson, R. R., and Stevens, H. E., Papaya production in the United States, Circ. No. 633, Washington, D.C., 1942.

11. Tripathi, R. D., A review on papaya manuring, Annual Report for 1957-59, Fruit Res. Sta., Saharanpur Dept. Agr., Uttar Pradesh, Saharanpur, 1959.

12. Wolfe, H. S., and Lynch, S. J., Papaya culture in Florida, Fla. Agr. Exp. Sta. Bul. 350, Gainesville, Fla. 1940. 